\title{
Influence Of Financial Audit Findings, Governments Wealth, Size Of Government And Leverage On The Performance Of Regency/City Governments In Indonesia
}

\author{
Andri Nugraha \\ Department of Accounting, Univesity Of North Sumatra, Indonesia
}

\begin{tabular}{|c|c|}
\hline ARTICLE INFO & ABSTRACT \\
\hline Article history: & \multirow{8}{*}{$\begin{array}{l}\text { This study aims to determine the effect of BPK audit findings, } \\
\text { government's wealth, size of government as well as leverage on the } \\
\text { performance of local government districts / cities in Indonesia. The } \\
\text { analytical method used is descriptive analysis, Classical Assumption } \\
\text { Test, Multiple Linear Regression Analysis, Testing Hypothesis, and } \\
\text { the coefficient of determination. This study examined the relationship } \\
\text { between BPK audit findings with the performance of local } \\
\text { governments, government's wealth with local government } \\
\text { performance, size of government with local government } \\
\text { performance, as well as leverage the performance of local } \\
\text { governments. The population in this study are all local government } \\
\text { districts / cities in Indonesia, the sample in this study were } 47 \text { local } \\
\text { government districts / cities in Indonesia. The type of data in this } \\
\text { research is secondary data. The selection of the sampling method is } \\
\text { a purposive sampling method. And data processing using SPSS } \\
\text { software. The results contained in this research is the BPK audit } \\
\text { findings and leverage partially no significant effect on the } \\
\text { performance of the district / city in Indonesia. While the } \\
\text { government's negative wealth effect and the size of government has } \\
\text { positive influence on the performance of the government. And other } \\
\text { results are BPK audit findings, government's wealth, size of } \\
\text { government as well as leverage together have a significant influence } \\
\text { on the financial performance of the district / city in Indonesia. }\end{array}$} \\
\hline $\begin{array}{r}\text { Received Jul 10, } 2021 \\
\text { Revised Aug 25, } 2021 \\
\text { Accepted Aug 30, } 2021\end{array}$ & \\
\hline \multirow{7}{*}{$\begin{array}{r}\text { BPK Audit Findings; } \\
\text { Governments Wealth; } \\
\text { Size Of Government } \\
\text { Leverage; } \\
\text { Government Performance. }\end{array}$} & \\
\hline & \\
\hline & \\
\hline & \\
\hline & \\
\hline & \\
\hline & This is an open access article under the CC BY-NC license. \\
\hline \multicolumn{2}{|l|}{ Corresponding Author: } \\
\hline \multicolumn{2}{|c|}{$\begin{array}{l}\text { Andri Nugraha, } \\
\text { Department of Accounting, } \\
\text { University Of North Sumatara, Indonesa, } \\
\text { Jl. Dr. Mansur No. } 9 \text { Padang Bulan, Kec. Medan Baru, Kota Medan } 20222 . \\
\text { Email: andrinugraha@gmail.com }\end{array}$} \\
\hline
\end{tabular}

\section{INTRODUCTION}

Autonomy to the regions is based on the principle of decentralization in the form of broad, real and responsible autonomy. This autonomy is broad because the authority lies in the regions (such as in a federal state). Autonomy is real because it requires the authority to organize, grow, live and develop in the region. Meanwhile, autonomy is called responsible because the central government has handed over authority to the regions for the achievement of the objectives of regional autonomy. This is to improve public welfare services for a better, democratic, fair, equitable and harmonious relationship in the Republic of Indonesia.

The granting of broad autonomy and decentralization to districts and cities provides an avenue for local governments to make reforms in their regional financial management systems and 
regional budgets. In managing regional finances, local governments are required to manage regional finances that are public oriented (Mardiasmo, 2002). This includes demands for local governments to make financial reports and transparency of budget information to the public so that local government performance can be achieved.

According to Soeprapto (2003), there are many factors that influence the implementation and success of capacity building programs in local government. However, it can be specifically stated that in the context of regional autonomy, significant factors influencing capacity building include 5 (five) main points, namely, joint commitment, leadership, regulatory reform, institutional reform, and recognition of strengths and weaknesses.

In supporting the administration of the Government, the Regional Government prepares a financial budget which is then used as a guideline in carrying out its various activities. The budget in the Regional Government is commonly referred to as the Regional Revenue and Expenditure Budget (APBD). All local government revenues and expenditures in the form of money, goods and/services in the relevant fiscal year must be budgeted in the APBD (Kawedar, 2008). APBD is a unit consisting of regional income, regional expenditure and regional financing (Darise, 2008).

To support a better Regional Revenue and Expenditure Budget (APBD), public accountability is the most important element and is the main challenge faced by the government and civil servants. Accountability is in the social sciences involving various other branches of social science such as economics, administration, politics, behavior and culture. In addition, accountability can be interpreted as a form of obligation to account for the success or failure of the implementation of the organization's mission in. Achieve the goals and objectives that have been set previously, through a medium of accountability that is carried out periodically (Stanbury, 2003). So that public accountability can be carried out in a transparent manner with the aim of creating good governance, to make concrete efforts to realize good governance, as well as increasing transparency and accountability of government financial management, both the central government and local governments are required to submit accountability reports in the form of financial reports.

The problem of local government performance in Indonesia has been widely studied, but there are still few studies that examine the effect of local government characteristics and BPK audit findings on the performance of district/city local governments in Indonesia. This research is a replication of previous research. The difference between this study and previous research lies in the leverage variable. With this study, there are several reasons, namely using the performance of district/city local governments in Indonesia as the dependent variable and knowing the effect if leverage is applied in local governments. This research is very important because it can increase knowledge about public sector accounting and regional financial reporting.

\section{RESEARCH METHOD}

This study is a hypothesis testing study with the aim of testing the hypotheses that have been previously proposed regarding the findings of the BPK audit, government's wealth, size of government, and leverage on local government performance. Hypothesis testing aims to explain certain kinds of relationships, influences, determine group differences or independence on the performance of local governments.

The data used in this research is secondary data. Secondary data is a type of data obtained through certain sources indirectly. The source of the data used in this study is the data on the 2014 District/City Government Financial Reports in Indonesia

\subsection{Analysis Method}

\section{a. Descriptive Analysis}

Descriptive analysis is used to produce an overview of the data that has been collected. Descriptive analysis used in this study is the average (mean), maximum, minimum, and standard deviation.

\subsection{Classic assumption test}

The use of the classical assumption test aims to determine and test the feasibility of the regression model used in this study. Another objective is to ensure that the regression model used 
has data that are normally distributed, free from autocorrelation, multicollinearity and heteroscedasticity.

\section{a. Normality test}

The data normality test aims to test whether in the regression model, the independent variables, and the dependent variable have a normal distribution and not. In this normality test there are 2 ways to detect whether the residuals are normally distributed or not, namely by graphical analysis and statistical tests (Ghozali, 2011). The test equipment used is the analysis of histogram graphs and normal probability plot graphs and statistical tests with Kolmogorov-Smirnov Z (1-Sample KS).

\section{b. Autocorrelation Test}

The autocorrelation test aims to test whether in a linear regression model there is a correlation between the confounding error in a period and the previous period. Autocorrelation problems are often found in time series data or time series because disturbances in a company tend to affect disturbances in the same company in the next period. Meanwhile, in cross-sectional data, autocorrelation problems are relatively rare because disturbances in different observations come from different companies.

\section{c. Heteroscedasticity Test}

The heteroscedasticity test aims to test whether in the regression there is an inequality of variance from the residuals of one observation to another. If the residual variance from one observation to another observation is still called homoscedasticity. Meanwhile, if the residual variance from one observation to another is different, it is called heteroscedasticity. A good regression model is homoscedasticity, there is no heteroscedasticity by looking at the graph plot between the predicted value of the dependent variable, namely ZPRED with the residual value of SRESID. Detection of presence or absence can be done by looking at the presence or absence of a certain pattern on the Scatterplot graph between SRESID and ZPRED where the $Y$ axis is the predicted $\mathrm{Y}$, and the $\mathrm{X}$ axis is the residual ( $\mathrm{Y}$ predicted $-\mathrm{Y}$ actually) which has been standardized.

\section{RESULTS AND DISCUSSIONS}

\subsection{Descriptive Analysis}

Descriptive analysis is used to produce an overview of the data that has been collected. Descriptive analysis used in this study is the average (mean), maximum, minimum, and standard deviation.

Table 1. Descriptive Statistics Results Descriptive Statistics

\begin{tabular}{lccccc}
\hline & $\mathrm{N}$ & Minimum & Maximum & mean & Std. Deviation \\
\hline BPK Audit Findings & 47 & .00 & 2.00 & .9574 & .75058 \\
Government's Wealth & 47 & 10.13 & 15.66 & 13.3214 & 1.27716 \\
Size & 47 & 27.63 & 30.83 & 28.8733 & .76917 \\
Leverage & 47 & .00 & 2.21 & .4851 & .59189 \\
Government Performance & 47 & .79 & 1.39 & 1.0041 & .11590 \\
Valid N (listwise) & 47 & & & & \\
\hline Source & & & &
\end{tabular}

Source: Results of data processing with SPSS, 2016

Based on table 1 above, it can be seen that the BPK audit findings variable has a minimum value of 0.00 and a maximum value of 2.00. The mean value for BPK audit findings is 0.9574 and the value of Std. Deviation 0.75058 with a total of 47 samples of observations.

The government's wealth variable has a minimum value of 10.13 and a maximum value of 15.66. The mean value for government's wealth is 13.3214 and the value of Std. Deviation 1,27716 with a total of 47 samples of observations.

The variable size of government has a minimum value of 27.63 and a maximum value of 30.83. The mean value for the size of government is 28.8733 and the value of Std. Deviation 0.76917 with a total of 47 samples of observations. 
The leverage variable has a minimum value of 0.00 and a maximum value of 2.21. The mean value for leverage is 0.4851 and the value of Std. Deviation 0.59189 with a total of 47 samples of observations.

The government performance variable has a minimum value of 0.79 and a maximum value of 1.39. The mean value for government performance is 1.0041 and the value of Std. Deviation 0.11590 with a total of 47 samples of observations.

\subsection{Classic assumption test}

The classical assumption test was carried out to ensure that in this study there was no multicollinearity, autocorrelation and heteroscedasticity, and the resulting data had a normal distribution. If there is no multicollinearity, autocorrelation and heteroscedasticity found, then the classical assumption has been fulfilled.

\section{a. Normality test}

The normality test in this study was carried out using the One Sample Kolmogorov-Smirnov Test. In the One-Sample Kolmogorov-Smirnov Test, a data is said to have a normal distribution if the significance value or the Asymp value. Sig. (2-tailed) is greater than 0.05 . So, decision making in this test is based on:

1) If the results of the One-Sample Kolmogorov-Smirnov above the 0.05 level of significance indicate a normal distribution pattern, then the regression model meets the assumption of normality.

2) If the results of One Sample Kolmogorov-Smirnov below the 0.05 level of significance do not show a normal distribution pattern, then the regression model does not meet the assumption of normality.

Normality test results are presented in Table 2 as follows.

Table 2. Normality Test Results

One-Sample Kolmogorov-Smirnov Test

\begin{tabular}{|c|c|c|}
\hline & & $\begin{array}{c}\text { Unstandardized } \\
\text { Residual }\end{array}$ \\
\hline $\mathrm{N}$ & & 47 \\
\hline Normal Parameters,,b & mean & .0000000 \\
\hline Most Extreme Differences & $\begin{array}{l}\text { Std. Deviation } \\
\text { Absolute }\end{array}$ & $\begin{array}{c}.10308897 \\
.190\end{array}$ \\
\hline & Positive & .190 \\
\hline & negative & -.136 \\
\hline $\begin{array}{l}\text { Kolmogorov-Smirnov Z } \\
\text { asymp. Sig. (2-tailed) }\end{array}$ & & $\begin{array}{l}1.304 \\
.067\end{array}$ \\
\hline
\end{tabular}

Table 2 shows that the Asymp value. Sig. (2-tailed) of 0.067 is greater than 0.05 . So it can be concluded that the data tested in this study are normally distributed. In addition to the results of the one-sample Kolmogorov Smirnov test, the author also displays the results of the normality test using a graph test to support the results of the one-sample Kolmogorov Smirnov test.

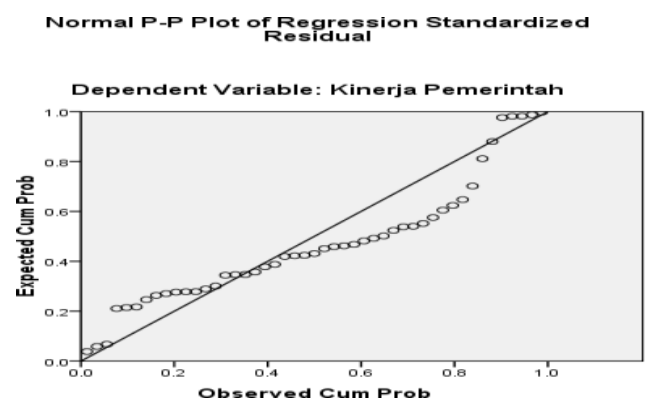

Figure 1. Graph Test Results 
If the data distribution is normal, then the line that represents the actual data will follow the diagonal line. Seen from Figure 1 above, the results of the graph test using the PP plot show that the points spread around the diagonal line and their distribution follows the direction of the diagonal line. This graph shows that the regression model is feasible to use because it meets the assumption of normality.

\section{b. Autocorrelation Test}

Autocorrelation test aims to determine whether in a linear regression model there is a correlation between the confounders in period t and errors in period t-1 (previous). The analytical tool used is the Durbin Watson Statistical test with the following conditions:

1) If the Durbin Watson (DW) value lies between the upper limit or Upper Bound (DU) and $4-$ $\mathrm{DU}$, then the autocorrelation coefficient is zero, meaning there is no autocorrelation.

2) If the DW value is lower than the lower limit or Lower Bound (DL), then the autocorrelation coefficient is greater than zero, meaning that there is a positive autocorrelation.

3) If the value of DW is greater than (4-DL), then the autocorrelation coefficient is smaller than zero, meaning that there is a negative autocorrelation.

4) If the value of DW lies between the upper limit (DU) and the lower limit (DL) or DW lies between (4-DU) and (4-DL), then the results cannot be concluded.

In this study, because it uses $\mathrm{n}=47, \mathrm{k}=5$ so that according to the Durbin Watson table at the level of significance 0.05 , it is known that $\mathrm{dl}=1.3073 \mathrm{du}=1.7736$, $4-\mathrm{du}=2.2264$, and 4 -dl $=$ 2.6927

Table 3. Autocorrelation Test Results Model Summaryb

\begin{tabular}{cccccc}
\hline Model & $\mathrm{R}$ & $\mathrm{R}$ Square & Adjusted R Square & d. Error of the Estimate & Durbin-Watson \\
\hline 1 & $.457 \mathrm{a}$ & .209 & .134 & .10789 & 2.134 \\
\hline
\end{tabular}

Source: Results of data processing with SPSS

Based on Table 3, the Durbin Watson (DW) value lies between the upper limit or Upper Bound (du) and 4-du, namely $1.7736<2.134<2.2264$. Then the autocorrelation coefficient is equal to zero, which indicates that there is no autocorrelation or there is no correlation between the confounding error in a period and the previous period in the regression model of this study.

\section{c. Heteroscedasticity Test}

The heteroscedasticity test aims to test whether in the regression there is an inequality of variance from the residuals of one observation to another. If the residual variance from one observation to another observation is still called homoscedasticity. Meanwhile, if the residual variance from one observation to another is different, it is called heteroscedasticity.

A good regression model is homoscedasticity, there is no heteroscedasticity by looking at the graph plot between the predicted value of the dependent variable, namely ZPRED with the residual value of SRESID. Detection of presence or absence can be done by looking at the presence or absence of certain patterns on the Scatterplot graph between SRESID and ZPRED where the $Y$ axis is the predicted $Y$, and the $X$ axis is the residual ( $Y$ predicted - actual $Y$ ).

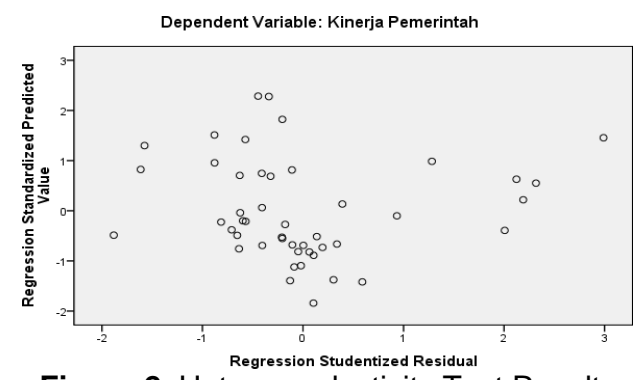

Figure 2. Heteroscedasticity Test Results 
From the results of the heteroscedasticity test, it can be seen that there is no clear pattern, and the points spread above and below the number 0 on the $Y$ axis, it can be concluded that there is no heteroscedasticity in this research model.

\section{d. Multicollinearity Test}

This test aims to test whether the regression model found a correlation between the independent variables (independent). A good regression model should not have a correlation between the independent variables. Provisions in the multicollinearity test:

If the Tolerance value $>0.10$ and VIF $<10$, it can be interpreted that there is no multicollinearity in the study. If the value of Tolerance $<0.10$ and VIF $>10$, it can be interpreted that there is a multicollinearity disorder in the study.

Table 4. Multicollinearity Test Results Coefficientsa

\begin{tabular}{llcc}
\hline \multicolumn{1}{c}{ Model } & \multicolumn{2}{c}{ Collinearity Statistics } \\
& Tolerance & VIF \\
\hline 1 & (Constant) & & \\
BPK Audit Findings & .869 & 1.151 \\
Government's Wealth & .848 & 1.180 \\
Size & .807 & 1,240 \\
Leverage & .822 & 1.217 \\
\hline \multicolumn{2}{l}{ Source: Results of data processing with SPSS, 2016 }
\end{tabular}

Based on Table 4, it can be concluded that there is no symptom of multicollinearity in the interaction of BPK audit findings, government's wealth, size of government and leverage on government performance because each tolerance value is above 0.10 and the VIF value is below 10.

\subsection{Multiple Linear Regression Analysis}

The analytical technique used in this study is multiple linear regression analysis to describe the effect of BPK audit findings, government's wealth, size of government and leverage on government performance. The results of the regression analysis can be seen in the following table:

Table 5. Multiple Linear Regression Analysis Results Coefficientsa

\begin{tabular}{|c|c|c|c|c|c|c|}
\hline \multicolumn{2}{|r|}{ Model } & \multicolumn{2}{|c|}{ Unstandardized Coefficients } & \multirow{2}{*}{$\begin{array}{c}\text { Standardized } \\
\text { Coefficients } \\
\text { Beta }\end{array}$} & \multirow[t]{2}{*}{ t } & \multirow[t]{2}{*}{ Sig. } \\
\hline & & B & Std. Error & & & \\
\hline \multirow[t]{5}{*}{1} & (Constant) & .141 & .618 & & 229 & .820 \\
\hline & BPK Audit Findings & .005 & .023 & 036 & 242 & 810 \\
\hline & Government's Wealth & -.042 & 014 & -.458 & -3.070 & .004 \\
\hline & Size & .049 & .023 & .327 & 2,142 & .038 \\
\hline & Leverage & -.028 & .030 & -141 & -.930 & .358 \\
\hline
\end{tabular}

\subsection{Hypothesis Testing}

\section{a. $\quad$ F Statistic Test (F-test)}

The $F$ test is used to see the effect of BPK audit findings, government's wealth, size of government and leverage on government performance simultaneously. This effect needs to be tested to see whether this regression model can be continued by performing a t-test (partial) or not.

If the results of the $F$ test have a significant effect, then this regression model can be continued by performing a $t$ test. On the other hand, if it has no effect, then the t-test (partial test) cannot be carried out, because all independent variables do not affect the dependent variable. The following is a table of $F$ test results. 
Table 6. F Test Results ANOVAb

\begin{tabular}{ccccccc}
\hline & Model & Sum of Squares & df & Mean Square & F & Sig. \\
\hline 1 & Regression & .129 & 4 & .032 & 2,773 & $.039 a$ \\
& Residual & .489 & 42 & .012 & & \\
& Total & .618 & 46 & & &
\end{tabular}

Based on the table above, it can be seen that the $F$ test results show a significant value of 0.039 which is smaller than 0.05 . The results of this $F$ test indicate that the independent variables simultaneously (simultaneously) have a significant influence on the dependent variable, namely government performance. To see what independent variables have an effect on government performance, a t-test (partial test) is carried out.

\section{b. T-Statistic Test (T-test)}

The t-statistical test basically shows how far the influence of one independent variable individually in explaining the dependent variable. The hypothesis is formulated as follows:

$\mathrm{HO}: \mathrm{Xi}=0$, meaning that there is no significant effect of the independent variable on the dependent variable.

$\mathrm{H} 1: \mathrm{Xi}=0$, meaning that there is a significant effect of the independent variable on the dependent variable.

Acceptance or rejection of the hypothesis in a study can be done with the following criteria:

1) If the significance value of $t$ statistic $>0.05$, then $\mathrm{HO}$ is accepted. This means that an independent variable individually has no influence on the dependent variable.

2) If the statistical significance value of $t<0.05$, then $\mathrm{HO}$ is rejected. This means that an independent variable individually affects the dependent variable.

Table 7. T Test Results (Partial) Coefficientsa

\begin{tabular}{ccccccc}
\hline & Model & \multicolumn{2}{c}{ Unstandardized Coefficients } & Standardized & $\mathrm{t}$ & Sig. \\
& & $\mathrm{B}$ & Std. Error & Befficients \\
Beta & & & \\
\hline 1 & (Constant) & .141 & .618 & & .229 & .820 \\
BPK Audit Findings & .005 & .023 & .036 & .242 & .810 \\
Government's Wealth & -.042 & .014 & -.458 & -3.070 & .004 \\
Size & .049 & .023 & .327 & 2,142 & .038 \\
& Leverage & -.028 & .030 & -141 & -.930 & .358 \\
\hline
\end{tabular}

Source: Results of data processing with SPSS, 2016

Based on Table 7, the results of the regression test analysis state that the BPK audit findings and leverage have no partial (individual) significant effect on government performance. However, government's wealth and size of government partially have a significant effect on government performance.

The BPK audit findings have a t significance value of $0.810>0.05$, meaning that the BPK audit findings partially have no significant effect on government performance. Government's wealth has a significance value of $t$ of

$0.004<0.05$, meaning that government's wealth partially has a significant effect on government performance. Size of government has a significance value of $t$ of $0.038<0.05$, meaning that the size of government partially has a significant effect on government performance. Leverage has a significance value of $t$ of $0.358>0.05$, meaning that partial leverage has no significant effect on government performance.

\subsection{Coefficient of Determination Test}

The coefficient of determination (R2) essentially measures how far the model's ability to explain the variation of the dependent variable. The value range is 0 to 1 , if the value of $R 2$ is small, it means that the ability of the independent variables in explaining the variation of the 
dependent variable is very limited, on the other hand, if $R 2$ is large (close to the value of 1 ), it means that the ability of the independent variables to explain the variation of the dependent variable is large. The value of $\mathrm{R} 2$ can be seen in the following table 8 .

Table 8. Coefficient of Determination Test Results (R2) Model Summaryb

\begin{tabular}{ccccc}
\hline Model & $\mathrm{R}$ & $\mathrm{R}$ Square & Adjusted R Square & $\begin{array}{c}\text { Std. Error of the } \\
\text { Estimate }\end{array}$ \\
\hline 1 & $.457 \mathrm{a}$ & .209 & .134 & .10789 \\
\hline Source: Results of data processing with SPSS, 2016 &
\end{tabular}

Based on table 8, the value of $R$ Square (R2) is 0.209 , which means 0.209 or $(20.9 \%)$ the independent variables, namely the findings of the BPK audit, government's wealth, size of government and leverage are able to explain government performance. While the remaining $79.1 \%$ is influenced or explained by other variables that are not included in the research model.

\section{CONCLUSION}

BPK audit findings have no significant effect on the performance of district/city governments in Indonesia. With these results, $\mathrm{H} 1$ is rejected.

Government's wealth has a negative and significant effect on the performance of district/city governments in Indonesia. With these results, $\mathrm{H} 2$ is rejected.

Size of government positive and significant effect on the performance of district/city governments in Indonesia. With these results, $\mathrm{H} 3$ is accepted.

Leverage does not have a significant effect on the performance of district/city governments in Indonesia. With these results, $\mathrm{H} 4$ is accepted.

The findings of the BPK audit, government's wealth, size of government and leverage simultaneously have a significant effect on the performance of district/city governments in Indonesia. With these results, $\mathrm{H} 5$ is accepted.

\section{REFERENCES}

Abdullah, Syukriy dan J.A. Asmara. 2006. Perilaku Oportunistik Legislatif dalam Penganggaran Daerah: Bukti Empiris atas Aplikasi Agency Theory di Sektor Publik. Simposium Nasional Akuntansi Padang, 23-26 Agustus 2006.

Adi, Priyo Hari. 2006, Hubungan Antara Pertumbuhan Ekonomi, Belanja Pembangunan dan Pendapatan Asli Daerah. Proceddding Simposium Nasional Akuntansi IX, Padang.

Arens, Alvin A. (2008). Auditing and assurace services: an intergated approach.Ed.12th. Pearson Education: USA.

Azhar, Susanto. 2008. Sistem Informasi Akuntansi, Struktur Pengendalian Resiko Pengembangan, Edisi Perdana, Bandung: Lingga Jaya.

Badan Pemeriksa Keuangan Republik Indonesia. Ikhtisar Hasil Pemeriksaan Semester 1 Tahun 2014. http://www.bpk.go.id

Badan Pemeriksa Keuangan Republik Indonesia. Ikhtisar Hasil Pemeriksaan Semester 2 Tahun 2014. http://www.bpk.go.id

Bastian, I. 2001. Akuntansi Sektor Publik di Indonesia. Yogyakarta: BPFE. 2006.Akuntansi Sektor Publik. Jakarta: Erlangga.

Bhinadi, Ardhito. 2003. Disparitas Pertumbuhan Ekonomi Jawa dengan Luar Pulau Jawa. Jurnal Ekonomi Pembangunan Vol. 8 No. 1: 39-48. Juni 2003.

Chow, C.W., Ganulin, D., Haddad, K. and Williamson, J. 1998. The balanced scorecard: a potent tool for energizing and focusing health-care organization management. Journal of Health-care Management.

Damanpour, F. 1991. Organizational innovation: A meta-analysis of effects of determinants and moderators. Academy of Management Journal, Vol. 34: 555590.

Daulay, Murni. 2010. Metode Penelitian Ekonomi. Medan: USU Press.

Doyle, J., Weili Ge dan Sarah McVay, 2006. Determinants of Weaknesses in Internal Control over Financial Reporting. Journal of Accounting and Economics. www.elsevier.com.

Erlina, 2008, Metode Penelitian Bisnis untuk Akuntansi dan Manajemen, Cetakan Pertama. Medan: usu Press 
Fitriyanti, Ismi Rizky dan Pratolo, Suryo. 2009. Pengaruh Pendapatan Asli Daerah dan Belanja Pembangunan Terhadap Rasio Kemandirian dan Pertumbuhan Ekonomi. Penelitian keuangan akuntansi sektor publik II Badan Litbang Departemen dalam Negeri, Bidakara, 2-3 Juni 2009.

Ghozali, Imam. 2011. Aplikasi Analisis Multivariate Dengan Program SPSS. Semarang: Badan Penerbit Universitas Diponegoro.

Greiling, Dorothea. 2005. Performance Measurement in The Public Sector: The German Experience. Emerald Research, Vol. 54: 551-567.

Halachmi, Arie. 2005. Performance measurement is only one way of managing performance. International Journal of Productivity and Performance Management. Vol. 54: 502-516.

Halim, Abdul. 2004. Akuntansi Sektor Publik: Akuntansi Keuangan Daerah. Jakarta: Salemba Empat.

Hamzah, Ardi. 2008. Analisa Kinerja Keuangan Terhadap Pertumbuhan Ekonomi, Pengangguran, Dan Kemiskinan: Pendekatan Analisis Jalur (Studi Pada 29 Kabupaten Dan 9 Kota Di Propinsi Jawa Timur Periode 2001 - 2006) Simposium nasional akuntansi 11.

Handra, Hefrizal dan Maryati, Sri. 2009. Analisis Pendapatan Asli Daerah (PAD) Bukan Pajak Pemerintah Propinsi Sumatra Barat. Konferensi Penelitian Keuangan Sektor Publik II Badan Litbang Departemen Dalam Negeri.

Jensen, Michael C., William H. Mecling, 1976, Theory of the Firm: Managerial Behavior, Agency Costs and Ownership Structure, The Journal of Financial Economics

Kuncoro, Mudrajad. 2004. Otonomi dan Pembangunan Daerah Reformasi, Perencanaan, Strategi dan Peluang. Jakarta. Erlangga.

Kusumawardani. 2012. Pengaruh Karakteristik Daerah (size, Kemakmuran, ukuran, legislatif, leverage) Terhadap Kinerja Keuangan Pemerintah Daerah. Accounting Analysis Journal 1. Universitas Negeri Semarang.

Mardiasmo. 2004. Akuntansi Sektor Publik. Yogyakarta: Andi.

Minarsih, Ratna Ayu. 2015. Pengaruh Size, Wealth, Leverage Dan Intergovernmental Revenue Terhadap Kinerja Keuangan Pemerintah Daerah Di Jawa Tengah. Skripsi. Universitas Negeri Semarang. Semarang.

Nordiawan, Deddi dan Hertianti, Ayuningtyas. 2011. Akuntansi Sektor Publik.Salemba Empat. Jakarta.

Patrick, P. A. 2007. The Determinant of Organizational Inovativeness: The Adoption of GASB 34 in Pennsylvania Local Government. Dissertation. The Pennsylvania State University. Pennsylvania.

Rukmana, Wan Widi. 2013. Pengaruh Pajak Daerah, Retribusi Daerah dan Dana Perimbangan Terhadap Kinerja Keuangan Pemerintah Provinsi Kepulauan Riau.Jurnal Fakultas Ekonomi. Universitas Maritim Raja Ali

Sugiyono, 2006. Statistika untuk Penelitian, cetakan kesembilan, Alfa Beta, Bandung.

Suhardjanto, D, Rusmin, Mandasari, Putriesti and Brown, Alistair. 2010. Mandatory Disclosure Compliance and Local Government Charactheristics: Evidence from Indonesian Municipalities. Journal Public Policy January 2010

Sumarjo, Hendro. 2010. Pengaruh Karakteristik Pemerintah Daerah terhadap Kinerja Keuangan Pemerintah Daerah. Skripsi. Fakultas Ekonomi Universitas Sebelas Maret. Surakarta.

Suyono. 2010. Analisis Kinerja Keuangan Pemerintah Daerah. Tesis. Surakarta: Fakultas Ekonomi. Universitas Sebelas Maret.

Syafitri, Febriyani. 2012. Analisis Pengaruh Karakteristik Pemerintah Daerah terhadap Tingkat Pengungkapan Laporan Keuangan. Skripsi. Fakultas Ekonomi Universitas Indonesia. Depok.

Westin, Susan S. 1998. Performance Measuremnt and Evaluation Definition and Relationship. GAO issued May 2005

Wood, L. 1998. Local Government Dollars \& Sense (Rancho Palos Verdes, CA: Training Shoppe). 